\title{
Fractionation and Bioavailability of Trace Elements in Wuyi Rock Tea Garden Soil
}

\author{
Hongmeng Ye ${ }^{1,2 *}$, Guoping Li ${ }^{1}$, Xuyin Yuan ${ }^{1,2}$, Maozhong Zheng ${ }^{1}$ \\ ${ }^{1}$ Fujian Provincial Key Laboratory of Eco-Industrial Green Technology, College of Ecology and Resource Engineering, \\ Wuyi University, Wuyishan, Fujian 354300, P.R. China \\ ${ }^{2}$ Key Laboratory for Integrated Regulation and Resource Development on Shallow Lakes, Ministry of Education, \\ College of the Environment, Hohai University, Nanjing, Jiangsu 210098, P.R. China
}

Received: 25 May 2017

Accepted: 10 July 2017

\begin{abstract}
The chemical fraction of elements has been widely employed in the study of soil chemistry, plant nutrition, and environmental science. For this study we conducted a comprehensive survey on trace elements ( $\mathrm{Hg}, \mathrm{As}, \mathrm{Cd}, \mathrm{Cr}, \mathrm{Pb}, \mathrm{Cu}, \mathrm{Zn}, \mathrm{Mn}, \mathrm{Se}, \mathrm{Mo}, \mathrm{Co}$, etc.) from the rock tea gardens in Wuyishan, southeastern China. Our results demonstrate that:

1) The contents of heavy metals such as $\mathrm{Hg}, \mathrm{Pb}, \mathrm{As}$, and $\mathrm{Cd}$ in the soil meet the environmental requirements for the growing area of tea (NY/T 853-2004), and the soil in the studied area contains sufficient Mn, Mo, and Se for tea plant growth, with a slight lack of Co.

2) The exchangeable fraction is determined to be the dominant fraction of $\mathrm{Cd}$, which originates from an anthropogenic source and possesses high bioavailability from elemental speciation analysis.

3) The heavy metal contents in all the tea leaf samples are within the safe range, and the average values of the element enrichment coefficients of the tea leaves decrease in the order: $\mathrm{Mn}>\mathrm{Cu}>\mathrm{Hg}>\mathrm{Zn}>\mathrm{Se}>$ $\mathrm{Cd}>\mathrm{Mo}>\mathrm{Co}>\mathrm{As}>\mathrm{Pb}>\mathrm{Cr}$.
\end{abstract}

Keywords: trace elements, fractionation, bioavailability, Wuyi rock tea, enrichment coefficient

\section{Introduction}

Recently, the chemical fraction of elements has received extensive attention by the soil chemistry, plant nutrition, and environmental science communities [12]. The various fractionation techniques have shown a significant impact on eco-environmental research, such as environmental activity, bioavailability, and toxicity [3-4]. Fractionation takes advantage of the chemical speciation distribution and the variations of the contents of elements

*e-mail: hongmengye@sina.com to evaluate biological availability [5-7]. Therefore, it is beneficial for the comprehensive study on the harmfulness of trace elements and the treatment of polluted soil [8-10].

Tea is one of the most consumed nonalcoholic beverages, which possesses numerous benefits for human health, including anticancer, antioxidant properties, reduction of free radicals, and other unique health advantages [11]. However, in recent years reports have suggested that excessive amounts of trace elements are often found in tea [12-15]. Studies have confirmed that the soil from tea gardens is the primary source of trace elements in tea. The active forms of the elements can be directly absorbed and utilized by tea plants [8]. These 
active components play a crucial role in the metabolism, yield, quality, and other aspects of tea [11-14]. Therefore, study of the trace elements should not only focus on the total amount, but also analyze their chemical forms and especially biological availability. At present, environmental requirements for areal tea growth in China mainly focuses on the "five poisonous and harmful elements" ( $\mathrm{Hg}, \mathrm{As}, \mathrm{Cd}, \mathrm{Pb}$, and $\mathrm{Cr}$ ). However, other trace elements, including $\mathrm{Cu}, \mathrm{Zn}, \mathrm{Mo}, \mathrm{Co}$, Se, etc., have also attracted increasing attention by researchers [16].

As the birthplace of Chinese oolong and black teas, Wuyishan has a long history of tea production and is well known as the "tea kingdom." Wuyi rock tea, one of China's top-ranked teas, is often considered the best oolong tea, with the sweetness and freshness of black tea and fragrance of green tea. Nevertheless, little has been reported on the combination of trace elements in the soil as well as in the Wuyi rock tea leaves. The migration and influence of the trace elements are largely unknown. Furthermore, the ecological effects of the trace elements in the tea production area are mostly measured by total amount [17]. One can only comprehend the overall degree of pollution caused by the trace elements. It is difficult to distinguish natural sources from anthropogenic sources, or detect chemical activity and tea bioavailability. Moreover, the total amount of the trace elements cannot effectively evaluate the migration characteristics or predict potential ecological risks $[1,8]$.

In order to better understand the geochemical behavior of trace elements and its bioavailability and mobility in the rock tea garden soil, and provide a reference for the protection of ecological environment of the tea gardens (which ensures safety and quality of the tea), the objectives of the present study were:

- Evaluate the safety of trace elements in the soil and tea leaves.

- Identify trace elements fractions in rock tea garden soil.
- Evaluate the element bioavailability of soil and analyze main source.

- Explore the enrichment coefficient of trace elements in rock tea.

\section{Material and Methods}

\section{Overview of the Investigated Area}

Wuyishan city, located in Fujian Province of China and along the southeast slope of the northern section of Wuyi Mountain Range $\left(27^{\circ} 27^{\prime} 31^{\prime \prime} \sim 28^{\circ} 04^{\prime} 49^{\prime \prime}\right.$ N, 117 $37^{\prime} 22$ $118^{\circ} 19^{\prime} 44$ E), has a typical Danxia landform. The area has a typical subtropical monsoon humid climate, where it is warm in winter and cool in summer, with abundant rainfall throughout the year with average annual rainfall of 1,600-2,000 mm. The land types used in the basin are comprehensive, being mainly forest land and cultivated land, followed by urban land and other land types. The types of soil are mainly red soil, yellow soil, and paddy soil formed by sandy rock and granite. In 2002 Wuyi rock tea was nominated as "the protection of geographical origin of products" by the Fraction Bureau of Quality and Technical Supervision. Part of the Wuyi rock tea fields originates from the thick laminated purple conglomerate of the Cretaceous chishi group as the parent rock, and the other part originates from coarse-grained granite as the parent rock.

\section{Sample Selection}

Based on our field investigation, we collected both soil and tea leaf samples from 11 rock tea gardens in Wuyishan during April and May 2015. The tea leaves (spring tea) from these tea gardens are harvested only once a year in April or May, and are further cultivated and weeded in the fall. Tea seed cakes and oil-tea cakes are often used to

Table 1. Basic information of the tested samples from various rock tea gardens.

\begin{tabular}{|c|c|c|c|c|c|c|c|c|c|}
\hline $\begin{array}{l}\text { Sample } \\
\text { No. }\end{array}$ & $\begin{array}{c}\text { Sample } \\
\text { ID }\end{array}$ & Longitude & Latitude & $\begin{array}{l}\text { Altitude } \\
\text { (m) }\end{array}$ & $\begin{array}{l}\text { Soil } \\
\text { type }\end{array}$ & $\begin{array}{l}\text { Soil } \\
\mathrm{pH}\end{array}$ & $\begin{array}{l}\text { Soil } \\
\text { TOC }\end{array}$ & $\begin{array}{l}\text { Tea } \\
\text { type }\end{array}$ & $\begin{array}{c}\text { Tree age } \\
\text { /years }\end{array}$ \\
\hline 1 & Tianyou Peak & $117^{\circ} 56^{\prime} 43^{\prime \prime}$ & $27^{\circ} 38^{\prime} 48^{\prime \prime}$ & 249 & Purple soil & 4.66 & 40.12 & Shuixian & 25 \\
\hline 2 & Yunü Peak & $117^{\circ} 57^{\prime} 07^{\prime \prime}$ & $27^{\circ} 38^{\prime} 34^{\prime \prime}$ & 260 & Purple soil & 4.46 & 41.04 & Rougui & 25 \\
\hline 3 & Shuilian Hole & $117^{\circ} 58^{\prime} 57^{\prime \prime}$ & $27^{\circ} 40^{\prime} 59^{\prime \prime}$ & 414 & Purple soil & 4.59 & 46.12 & Rougui & 20 \\
\hline 4 & Lianhua Peak & $117^{\circ} 56^{\prime} 30^{\prime \prime}$ & $27^{\circ} 41^{\prime} 26^{\prime \prime}$ & 216 & Moist sandy soil & 4.48 & 32.38 & Dahongpao & 7 \\
\hline 5 & Lianhua Peak & $117^{\circ} 56^{\prime} 29^{\prime \prime}$ & $27^{\circ} 41^{\prime} 25^{\prime \prime}$ & 215 & Moist sandy soil & 4.66 & 32.45 & Dahongpao & 7 \\
\hline 6 & Hongxing Village & $117^{\circ} 49^{\prime} 04^{\prime \prime}$ & $27^{\circ} 39^{\prime} 48^{\prime \prime}$ & 226 & Moist sandy soil & 5.68 & 39.81 & Aijiaowulong & 2 \\
\hline 7 & Hongxing Village & $117^{\circ} 49^{\prime} 06^{\prime \prime}$ & $27^{\circ} 39^{\prime} 48^{\prime \prime}$ & 263 & Moist sandy soil & 5.78 & 38.89 & Aijiaowulong & 5 \\
\hline 8 & Chashan Col & $117^{\circ} 49^{\prime} 24^{\prime \prime}$ & $27^{\circ} 39^{\prime} 45^{\prime \prime}$ & 267 & Red soil & 5.02 & 42.21 & Shuixian & 18 \\
\hline 9 & Chashan Col & $117^{\circ} 49^{\prime} 27^{\prime \prime}$ & $27^{\circ} 39^{\prime} 34^{\prime \prime}$ & 304 & Red soil & 4.83 & 42.49 & Shuixian & 32 \\
\hline 10 & Chashan Col & $117^{\circ} 49^{\prime} 17^{\prime \prime}$ & $27^{\circ} 38^{\prime} 47^{\prime \prime}$ & 264 & Moist sandy soil & 4.61 & 41.72 & Dahongpao & 8 \\
\hline 11 & Yulong Valley & $117^{\circ} 49^{\prime} 48^{\prime \prime}$ & $27^{\circ} 38^{\prime} 45^{\prime \prime}$ & 274 & Red soil & 5.09 & 30.89 & Dahongpao & 13 \\
\hline
\end{tabular}


Table 2. Element contents according to different reference standards.

\begin{tabular}{|c|c|c|c|c|c|c|c|c|}
\hline & \multirow{2}{*}{ Reference standard } & \multicolumn{7}{|c|}{ Trace element contents/(mg/kg) } \\
\hline & & $\mathrm{Hg}$ & As & $\mathrm{Cd}$ & $\mathrm{Pb}$ & $\mathrm{Cr}$ & $\mathrm{Cu}$ & $\mathrm{Zn}$ \\
\hline Soil & $\begin{array}{l}\text { Environmental requirement for } \\
\text { growing area of tea [19] }\end{array}$ & 0.30 & 40 & 0.30 & 250 & 150 & - & - \\
\hline \multirow[b]{2}{*}{ Tea } & Green food-Tea [20] & - & - & - & 5 & - & 30 & - \\
\hline & $\begin{array}{c}\text { Maximum allowable levels for } \mathrm{Cr}, \mathrm{Cd} \text {, } \\
\mathrm{Hg}, \mathrm{As} \text {, and } \mathrm{F} \text { in the tea [21] }\end{array}$ & 0.3 & 2.0 & 1.0 & - & 5.0 & - & - \\
\hline
\end{tabular}

Note: "-" indicates not available for corresponding element levels in the standard.

fertilize and control pests in most of the rock tea gardens. A minority of gardens are also supplemented by chemical fertilizers and pesticides. The basic features of the test samples are shown in Table 1.

\section{Sample Collection and Processing Procedures}

In the selected tea gardens, according to the multipoint mixing method, five soil sampling points were set up in the shape of an "S." Previous studies showed that the soil of the rock tea gardens in Wuyishan was ploughed deeply, so that the vertical differentiation of the middle and trace elements among different layers (from 0 to $60 \mathrm{~cm}$ ) was not significant [17]. Therefore, taken from the $0-20 \mathrm{~cm}$ layer, the soil from each sampling point was placed together to form a mixture (about 1-2 kg), and then stored and cataloged. Tea leaf samples (about $0.5 \mathrm{~kg}$ ) were collected from fresh leaves of the rock tea trees corresponding to the soil samples.

In order to perform the element fraction analysis, the soil samples were first cleaned of gravel, plant roots, dead branches, and other impurities. Subsequently, the soil samples were milled, dried in natural atmosphere, and further purified by a 20-mesh sieve. Finally, the samples were mixed uniformly and quartered. For each measurement, $200 \mathrm{~g}$ of the soil samples were taken out, ground in an agate grinder, passed through a 100-mesh sieve, and properly stored. The tea leaf samples in fresh condition were rinsed repeatedly with tap water to remove adhesive dust and debris, and further rinsed two or three times with deionized water. The clean leaves were then dried in air at room temperature, followed by another drying at $60^{\circ} \mathrm{C}$ until constant weight. Subsequently, the dried leaves were crushed and filtered by an 80 -mesh sieve.

\section{Sample Analysis and Measurements}

So far, there are various monitoring technologies for element fraction analysis in which the most widely used technique is Tessier's five types of classification method of sequential extraction [3] and the three-step extraction method introduced by the European Standard Material Bureau (BCR) [4]. This study followed Tessier's classification method, which divides all chemical fractions into five types of different fractions: exchangeable, acidsoluble (carbonate-bound), ruducible (Fe/Mn-oxide bound), oxidizable (organically bound + sulphide-bound), and residual $[3,5]$. $\mathrm{Mn}, \mathrm{Co}, \mathrm{Mo}, \mathrm{Zn}, \mathrm{Cu}, \mathrm{Cr}, \mathrm{Pb}$, and $\mathrm{Cd}$ in the soil samples were digested in a $\mathrm{HCl}-\mathrm{HNO}_{3}-\mathrm{HClO}_{4}-$ HF digestion solution, and then measured using IRIS Advantage inductively coupled plasma optical emission spectroscopy (ICP-OES). As, Se, and $\mathrm{Hg}$ in the samples were digested in a $\mathrm{HCl}-\mathrm{HNO}_{3}$ digestion solution, and then measured by XGY1011 atomic fluorescence spectroscopy (AFS). The tea leaf samples were digested in a $\mathrm{HNO}_{3}$ $\mathrm{HClO}_{4}$ digestion solution, and measured using the same equipment as the soil samples. The detection limits and accuracy of the methods meet the evaluation requirements for ecological geochemical soil samples. The standard recovery is controlled in the range of $90-110 \%$. The total amount of various forms of the elements is above $80 \%$ and below $105 \%$ of the total elements, consistent with the requirements for morphological analysis. In addition, the $\mathrm{pH}$ value of each soil sample was analyzed in a 1:2.5 solid/ liquid ratio suspension using a combination $\mathrm{pH}$ electrode. Total organic carbon (TOC) in the soils was determined after treatment with $\mathrm{K}_{2} \mathrm{Cr}_{2} \mathrm{O}_{7} / \mathrm{H}_{2} \mathrm{SO}_{4}$ according to the Walkley-Black method [18]. Each index of the samples was tested three times, and the average value of the results is used as the statistical data.

\section{Reference Standard}

The main reference of the tea garden soil and the evaluation criteria of tea leaves are summarized in Table 2. The main standard of the trace elements in the tea garden soil is published in Environmental Requirements for Growing Area of Tea (NY/T 853-2004) [19]. The related standards of the trace elements in the tea leaves mainly include two standards: green food-tea (NY/T 288-2012) [20] and maximum allowable levels of $\mathrm{Cr}, \mathrm{Cd}, \mathrm{Hg}, \mathrm{As}$, and $\mathrm{F}$ in Tea (NY 659-2003) [21].

\section{Data Analysis}

Statistical analysis of the trace elements was conducted by the statistical software SPSS20.0, and the figure in this paper was compiled by Origin 9.0. 
Table 3. Trace element contents in various rock tea garden soil.

\begin{tabular}{|c|c|c|c|c|c|c|c|c|c|c|c|}
\hline \multirow{2}{*}{ Item } & \multicolumn{11}{|c|}{ Trace element contents in the soil/(mg/kg) } \\
\hline & $\mathrm{Hg}$ & As & $\mathrm{Cd}$ & $\mathrm{Pb}$ & $\mathrm{Cr}$ & $\mathrm{Cu}$ & $\mathrm{Zn}$ & $\mathrm{Mn}$ & $\mathrm{Se}$ & Mo & Co \\
\hline Max & 0.28 & 11.50 & 0.27 & 130.41 & 132.90 & 63.64 & 190.74 & 867 & 0.67 & 2.49 & 16.58 \\
\hline Min & 0.11 & 3.14 & 0.06 & 33.57 & 16.34 & 6.88 & 50.27 & 222 & 0.22 & 0.80 & 2.91 \\
\hline Mean & 0.18 & 6.69 & 0.12 & 69.39 & 93.59 & 29.83 & 110.03 & 432 & 0.43 & 1.47 & 9.02 \\
\hline $\mathrm{Sv}$ & 0.07 & 2.80 & 0.08 & 34.81 & 52.08 & 21.17 & 52.17 & 190 & 0.14 & 0.51 & 5.52 \\
\hline $\mathrm{CV} / \%$ & 36.73 & 41.79 & 67.97 & 50.17 & 55.65 & 70.96 & 47.41 & 43.91 & 33.36 & 34.67 & 61.18 \\
\hline
\end{tabular}

\section{Results and Discussion}

Physical and Chemical Characteristics of the Rock Tea Garden Soil

Our measurements demonstrate that the Wuyishan rock tea garden soil was acidic, with $\mathrm{pH}$ value between 4.21 and 5.78. Because tea trees are acid plants, the influence of acidity on the absorption of soil mineral elements is significant [8]. Previous studies have shown that optimum growth conditions require $\mathrm{pH}$ value between 4.5 and 5.5 [22]. The growth of tea plants is inhibited when the $\mathrm{pH}$ value is lower than 4.0, and slowed when the $\mathrm{pH}$ value is higher than 6.5. Higher $\mathrm{pH}$ value may even result in death of the tea trees [22]. It can be seen that the soil acidity of this tea area is basically suitable for the growth of tea plants. The organic matter content in the soil ranges 28.69$65.10 \mathrm{mg} / \mathrm{kg}$, which indicates good soil fertility and meets the standard of first-class soil fertility in the regulation of Technical Conditions of a Tea-Producing Area (NY/T 853-2004) [19].

The trace element measurement results are shown in Table 3. From the coefficient of variation, all the elements belong to the medium variation range $(10-100 \%)$, which
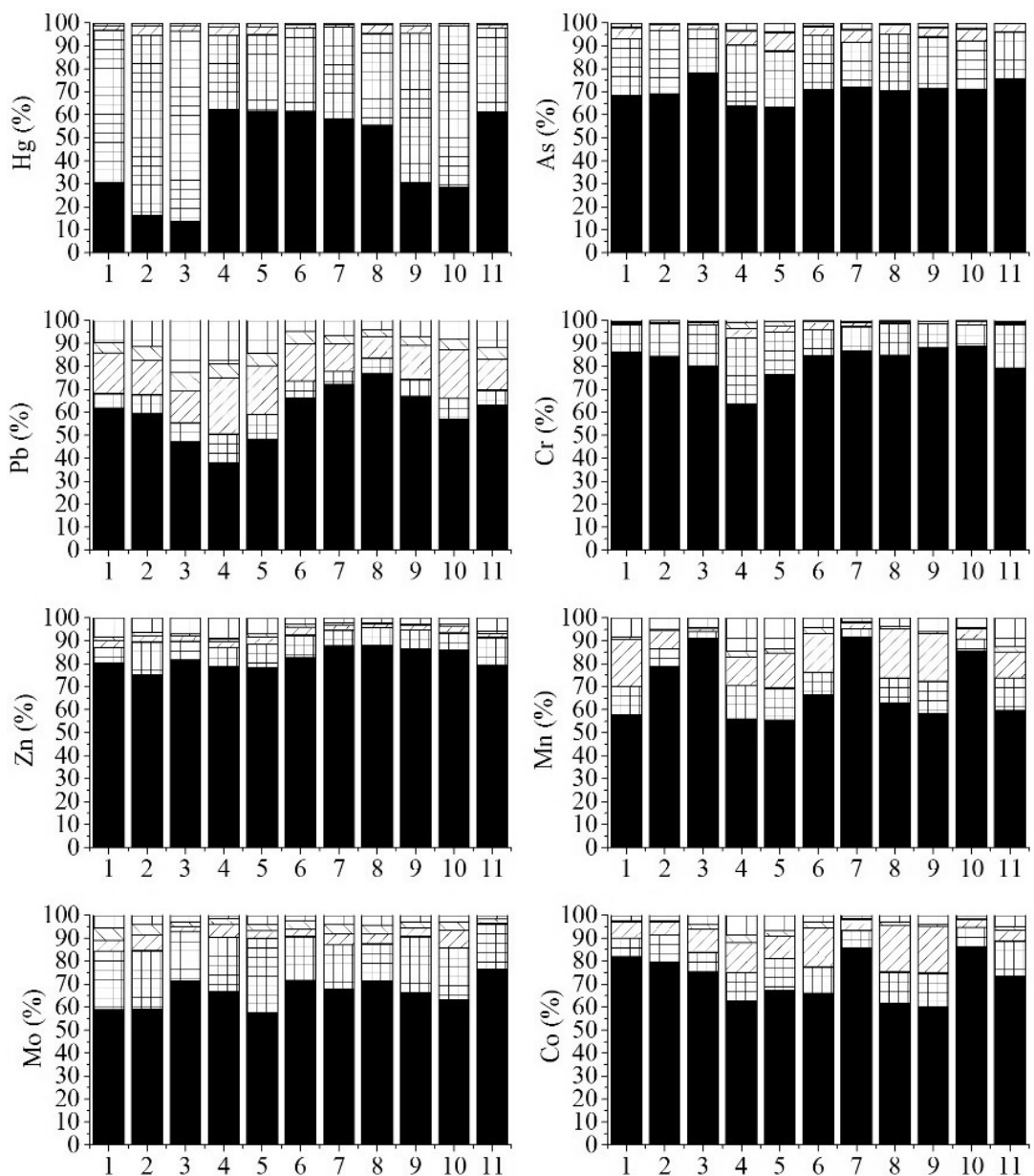

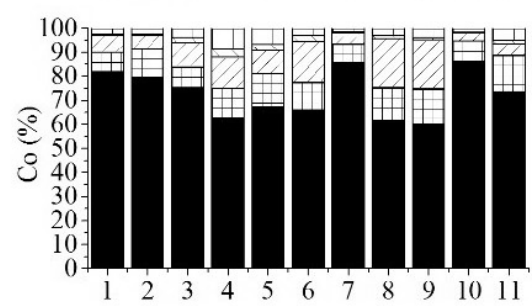

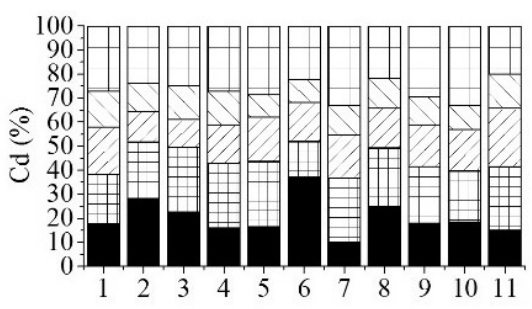
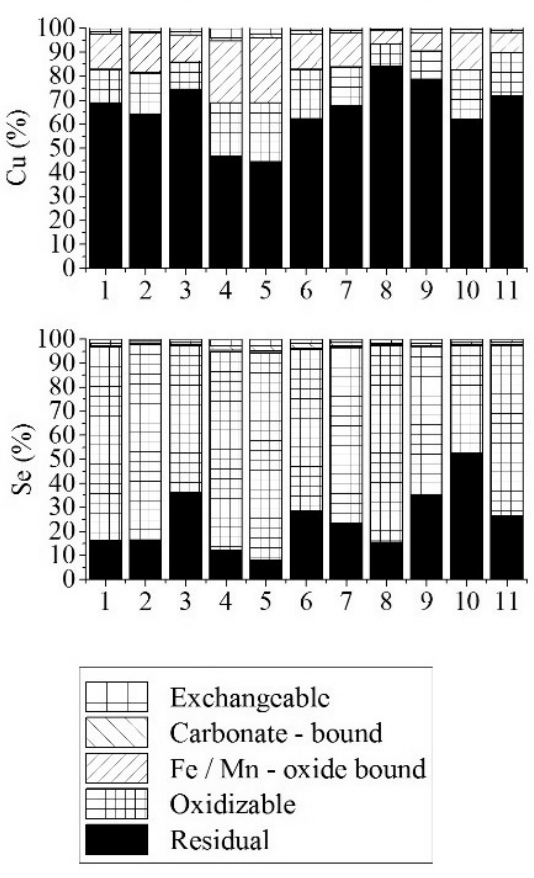

Fig. 1. The contents of various chemical fractions of trace elements in the soil. 
shows that the distribution of the trace element contents in the soil has a certain spatial variability. The mean values of the element contents decrease in the order: $\mathrm{Mn}>\mathrm{Zn}$ $>\mathrm{Cr}>\mathrm{Pb}>\mathrm{Cu}>\mathrm{Co}>\mathrm{As}>\mathrm{Mo}>\mathrm{Se}>\mathrm{Hg}>\mathrm{Cd}$, and their mean contents are $432 \mathrm{mg} / \mathrm{kg}, 110.03 \mathrm{mg} / \mathrm{kg}, 93.59$ $\mathrm{mg} / \mathrm{kg}, 69.39 \mathrm{mg} / \mathrm{kg}, 29.83 \mathrm{mg} / \mathrm{kg}, 9.02 \mathrm{mg} / \mathrm{kg}, 6.69 \mathrm{mg} /$ $\mathrm{kg}, 1.47 \mathrm{mg} / \mathrm{kg}, 0.43 \mathrm{mg} / \mathrm{kg}$, and $0.18 \mathrm{mg} / \mathrm{kg}, 0.12 \mathrm{mg} /$ $\mathrm{kg}$, respectively. Referring to the existing standard of tea garden soil (Table 2), the contents of $\mathrm{Hg}, \mathrm{As}, \mathrm{Cd}, \mathrm{Pb}$, and $\mathrm{Cr}$ are in accordance with the environmental requirements for growing area of tea (NY/T 853-2004) [19].

In addition, $\mathrm{Mn}$ is the most abundant heavy metal in the tea leaves, with a total amount reaching 222-867 mg/ $\mathrm{kg}$ in the studied area. The measured Mn content falls in the range of national soil content $(10-5,532 \mathrm{mg} / \mathrm{kg})$. The corresponding mean value is lower than the national average soil mean $(710 \mathrm{mg} / \mathrm{kg})$ [23], but higher than the manganese deficiency value $(<40 \mathrm{mg} / \mathrm{kg})$ [24]. For Co, compared with the Co critical value $(5 \mathrm{mg} / \mathrm{kg}$, which meets the need of ruminant [25]), to a certain extent, the tea garden soil in the studied area has insufficient Co (three soil samples, accounting for $27 \%$ of the total samples). The content of Mo in the rock tea area ranges from 0.80 to $2.49 \mathrm{mg} / \mathrm{kg}$, which belongs to the medium level (0.3-5 mg/kg) [26-27]. The content of Se ranges from 0.22 to $0.67 \mathrm{mg} / \mathrm{kg}$, in the range of sufficient selenium level $(0.175-0.450 \mathrm{mg} / \mathrm{kg})$ or high selenium level $(0.450-3.000 \mathrm{mg} / \mathrm{kg})$ [28].

\section{Fractionation Distribution Characteristics of Trace Elements}

Fig. 1 shows a histogram of 11 elements in the soil of Wuyi rock tea garden area. Among them, the average percentage of $\mathrm{Hg}$ fractions decrease in the order: oxidizable fraction $(53.84 \%)>$ residual fraction $(43.61 \%)>\mathrm{Fe}-\mathrm{Mn}$ oxide bound fraction $(2.50 \%)>$ exchangeable fraction $(1.02 \%)>$ carbonates fraction $(0.04 \%)$. Noticeably, the main fractions of $\mathrm{Hg}$ in the Wuyi rock tea garden area are oxidizable and residual fractions. The oxidizable fraction mainly refers to the complex or chelated fraction, in which the heavy metal elements are bounded to the organic matter. Thus, the heavy metals will gradually release to the environment when the organic matter decomposes, causing potential ecological risk to the soil [29].

The distribution of $\mathrm{Cd}$ is as follows: exchangeable fraction $(26.44 \%)>$ oxidizable fraction $(23.79 \%)>$ residue fraction $(20.46 \%)>$ Fe-Mn oxide bound fraction $(17.06 \%)$ $>$ carbonate fraction (12.24\%). Thus, exchangeable fraction is the dominant fraction of $\mathrm{Cd}$, which suggests that $\mathrm{Cd}$ can be easily absorbed by tea trees. Particularly, when the soil is acidic with high concentration of chloride ions, $\mathrm{Cd}$ exists mainly as coordination ions of chlorine [30], and about $95 \%$ of the $\mathrm{Cd}^{2+}$ can be absorbed by soil colloids. Therefore, the exchangeable fraction of $\mathrm{Cd}$ generally accounts for a higher proportion in the soil.

The distribution of Se is as follows: oxidizable fraction $(71.99 \%)>$ residual fraction $(24.57 \%)>$ exchangeable fraction $(1.66 \%)>$ carbonate fraction $(1.31 \%)>$ Fe-Mn oxide bound fraction $(0.47 \%)$. Visibly, the oxidizable fraction is dominant.

In addition, the chemical forms of $\mathrm{Pb}, \mathrm{Cr}, \mathrm{As}, \mathrm{Cu}$, $\mathrm{Zn}, \mathrm{Mn}, \mathrm{Mo}$, and $\mathrm{Co}$ are all dominated by the residue fraction, which accounts for 59.69\%, 86.40\%, 70.49\%, $65.89 \%, 82.21 \%, 69.40 \%, 66.43 \%$, and $72.67 \%$ of the total amount, respectively. In a word, we have identified the distribution of various trace elements through element fraction analysis.

\section{Evaluation of Bioavailability of Trace Elements in the Soil of the Tea Gardens}

\section{Risk Assessment Coding Method}

The risk assessment code (RAC) method is mainly used to analyze the activity patterns of the trace elements in the environment, and is also used as an indicator of ecosystem health $[8,31]$. RAC $=$ the content of activity fractions of elements (exchangeable and carbonate-bound fractions) / the total content of the element in all fractions [8]. The pollution degree of RAC assessment is "none" (RAC<1\%), "light" (1 10\%), "moderate" (10 30\%), "heavy" (30 50\%), and "very heavy" (RAC $\geq 50 \%)$ [8].

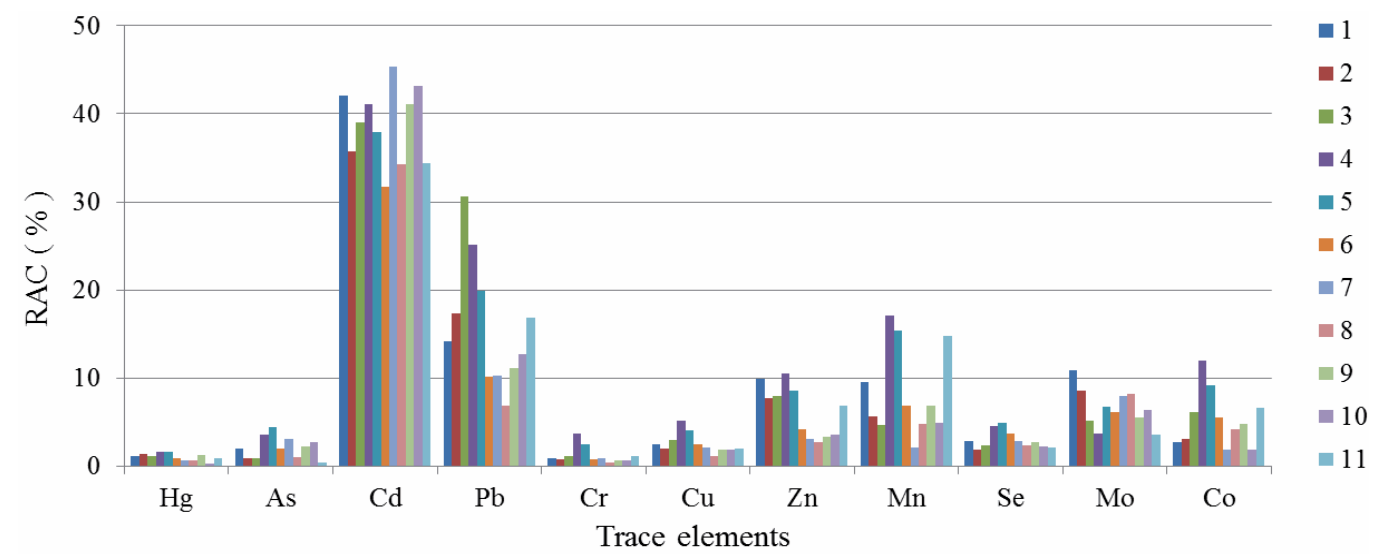

Fig. 2. RAC values of trace elements in the soil. 
Thus, the higher the RAC value, the greater the risk by the element to the environment $[8,31]$.

Fig. 2 shows the statistics of RAC values of trace elements taken from the 11 soil samples in the rock tea gardens from the studied area. The RAC risk assessment results show that the most serious pollution in the soil of Wuyi rock tea garden area comes from the element $\mathrm{Cd}$. The RAC values of $\mathrm{Cd}$ are $30-50 \%$, and $100 \%$ of the soil samples are polluted heavily by $\mathrm{Cd}$. This result is consistent with the above analysis of $\mathrm{Cd}$, in which the ion-exchange fraction dominates. Due to the weak mobility of $\mathrm{Cd}$ from the soil surface to the deep layer of soil, Cd can be longterm retained in the surface soil with high effectiveness for plant absorption [30]. Therefore, we should strengthen the investigation of the source of Cd pollutants, and take corresponding prevention and control measures in the teaproduction area.

$\mathrm{Pd}$ in all of the soil samples reaches the limit of environmental requirements for growing area of tea, and the residual fraction is the dominant fraction, but the soil samples with moderate and severe Pd pollution reach up to $91 \%$ from the RAC risk assessment. As a result, the biological effectiveness of the Pd element in the soil of the studied area is also higher.

In addition, the distribution of $\mathrm{Hg}, \mathrm{As}$, and $\mathrm{Cr}$ in the samples are no pollution or slight pollution. $\mathrm{Cu}$ and Se are all within the light pollution regime. $\mathrm{Zn}, \mathrm{Mn}, \mathrm{Mo}$, and Co show moderate pollution levels in a few rock tea gardens, and the majority of the gardens have light pollution. It can be seen that the evaluation of the ecological environment effect of the trace elements should combine the total element amount along with the chemical form component, so as to draw a more comprehensive and scientific conclusion.

\section{Ratio of Secondary Phase to Primary Phase Method}

The ratio of secondary phase to primary phase (RSP) method is often employed to distinguish the sources of trace elements, mainly from natural and anthropogenic sources, and can also reflect the bioavailability and chemical activity of the trace elements [32-33]. The RSP of trace elements is defined as the ratio of the content of secondary phase (all except the residue fraction) to the content of primary phase (residue fraction). In contamination-free conditions, most trace elements are distributed in mineral crystal lattice, and exist in iron and manganese oxides as granular inclusion membrane, dominated by residue fraction. However, in contaminated conditions, trace elements from anthropogenic sources mainly exist in the form of adsorbates. They may appear on the surface as particles or combine with organic matter, forming various weak binding fractions [33]. In a small area, the RSP value can be used to evaluate the degree of enrichment of the trace elements in the soil [32]. The pollution degree of RSP assessment is "none" $(\mathrm{RSP}<1)$, "light" (1-2), "moderate" (2-3), and "heavy" (RSP $\geq 3$ ) [24]. Therefore, the greater RSP reflects a higher degree of enrichment of the exogenous trace element.

According to Fig. 3, the soil samples show heavy pollution of Cd with RSP up to $82 \%$, indicating that the main source of $\mathrm{Cd}$ is anthropogenic with more biological effectiveness, which is consistent with the results of the RAC method mentioned above.

The samples with no and moderate pollution of $\mathrm{Hg}$ account for $55 \%$ and $45 \%$, respectively, which indicates that nearly half of the samples are affected by human activities to a great extent. It is likely that the $\mathrm{Hg}$ pollution is related to the application of fertilizers, pesticides, and other agricultural activities [17]. Although the activity ratio (RAC) is relatively low, the potential ecological risk is high, since $\mathrm{Hg}$ has strong toxicity, high mobility, high biological enrichment, and other characteristics that should be paid more attention.

The samples with light pollution of $\mathrm{Pb}$ account for $27 \%$, and all the other samples are not contaminated, indicating that $\mathrm{Pb}$ in the soil from the Wuyi rock tea garden area is mainly affected by natural sources with a little anthropogenic origin. The main anthropogenic source for $\mathrm{Pb}$ comes from traffic emissions, reflecting that although Wuyishan is a tourist city, the influence of the developing transportation on the tea garden soil is still weak, which is in good correspondence with the selection site of the

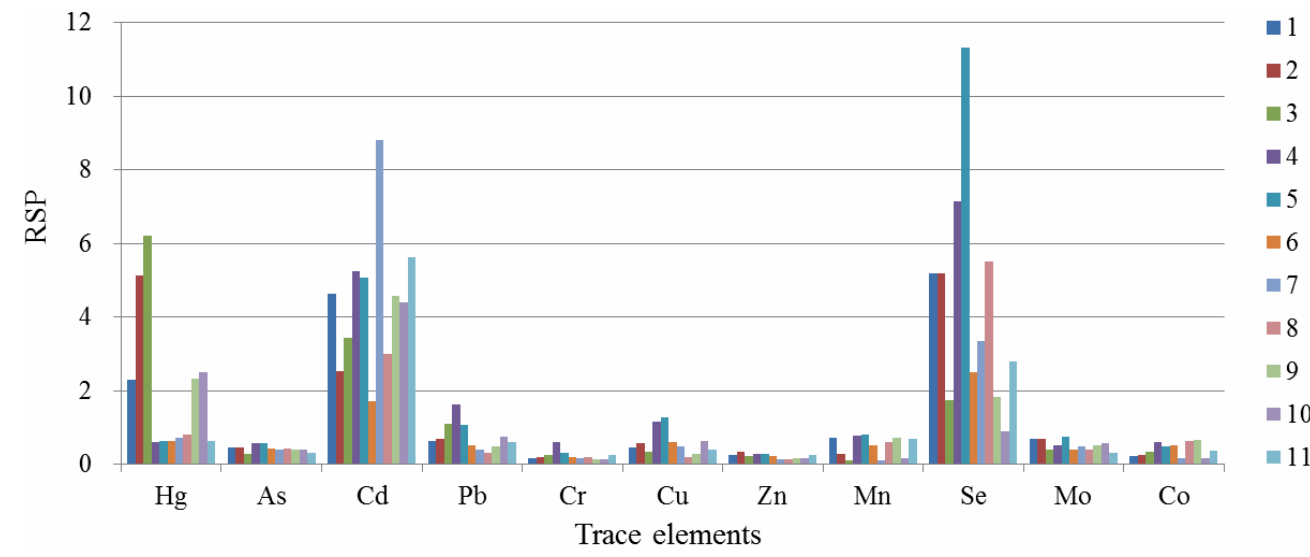

Fig. 3. RSP values and pollution degree assessment of trace elements in the soil. 
tea garden locations. The influence of traffic emissions can reach up to $320 \mathrm{~m}$ along both sides of the road, with the maximum value appearing at $5-20 \mathrm{~m}$ of the road on both sides [34].

The RSP value of Se was distributed in different pollution degrees, and is mainly in the heavy pollution regime with a RSP value of 55\%. This reflects the diversity of Se source in the soil of the tea garden area, partly dominated by natural sources, while most parts were affected by anthropogenic sources.

RSP of As, Cr, Zn, Mn, and Co in the soil samples are all less than 1 , which reflects that the dominate source of these elements in the studied area is natural. This is consistent with the analysis that the chemical fractions of these elements are dominated by residual fractions in the above study, and the ecological validity of the elements is weak - with little harm or beneficial to the tea

\section{Enrichment Effect of Trace Elements in Rock Tea Leaves}

\section{Content Characteristics of Trace Elements in Tea Leaves}

The contents of trace elements in tea leaves are shown in Table 4. The contents of the trace elements in the samples demonstrate apparent differences both in types and sample collection locations. The mean contents of the trace elements in rock tea decrease in the order: $\mathrm{Mn}>\mathrm{Zn}>\mathrm{Cu}>\mathrm{Co}>\mathrm{Cr}>\mathrm{Pb}>\mathrm{Se}>\mathrm{Mo}>\mathrm{Hg}>\mathrm{As}>$ $\mathrm{Cd}$. Among them, the content of $\mathrm{Mn}$ is highest. $\mathrm{Zn}$ and $\mathrm{Cu}$ content are relatively high among the contents of the trace elements. The content of $\mathrm{Cd}$ is lowest, which is consistent with other related research [35]. The content values of $\mathrm{Hg}, \mathrm{As}, \mathrm{Cd}, \mathrm{Pb}, \mathrm{Cr}$, and $\mathrm{Cu}$ of the tea leaf samples are $0.035-0.151 \mathrm{mg} / \mathrm{kg}, 0.040-0.065 \mathrm{mg} / \mathrm{kg}$, $0.013-0.057 \mathrm{mg} / \mathrm{kg}, \quad 0.164-0.369 \mathrm{mg} / \mathrm{kg}, \quad 0.198-0.775$ $\mathrm{mg} / \mathrm{kg}$, and $7.860-15.060 \mathrm{mg} / \mathrm{kg}$, respectively. According to the corresponding standard of green food-tea (NY/ T288-2012) [20] and maximum allowable levels of $\mathrm{Cr}$, $\mathrm{Cd}, \mathrm{Hg}, \mathrm{As}$, and F in tea (NY659-2003) [21], the contents of $\mathrm{Hg}, \mathrm{As}, \mathrm{Cd}, \mathrm{Pb}, \mathrm{Cr}$, and $\mathrm{Cu}$ of the tea leaf samples in the studied area are much lower compared to the standard limit (Table 2), satisfying all the safety requirements.

$\mathrm{Zn}$ and $\mathrm{Cu}$ are both essential trace elements for human health. Drinking tea is a good way to supplement their daily intake [24]. In a certain range, the grade of the tea and the amount of $\mathrm{Zn}$ and $\mathrm{Cu}$ contained in the tea are strongly correlated [25]. The content of Se in the tea from the studied area is lower than the standard of seleniumenriched tea $(0.2-0.4 \mathrm{mg} / \mathrm{kg})[24,28]$. This study showed that the mean of Mo in the fresh tea from Wuyi rock tea gardens is 0.068 (the range is $0.017-0.3230 \mathrm{mg} / \mathrm{kg}$ ). Previous studies indicated that the content of Mo in fresh tea shoots was generally between $0.1-1.0 \mathrm{mg} / \mathrm{kg}$. Samples contain less than $0.1 \mathrm{mg} / \mathrm{kg}$ is considered lack of Mo, and samples contain more than $5 \mathrm{mg} / \mathrm{kg}$ is excessive [27]. Therefore, the fresh tea in Wuyi rock tea gardens have a certain molybdenum deficiency problem. This is related to the low availability of Mo in the southern acid soil, and may also be related to the application of lime that leads to the low availability of cobalt [27]. Co is a necessary trace element, and the absolute content of Co in the tea is relatively low, while remaining below the standard limit. According to existing research, the content of $\mathrm{Co}$ in rock tea $(0.039-1.264 \mathrm{mg} / \mathrm{kg})$ in our study has been higher than the Co content of Oolong tea $(0.3 \mathrm{mg} / \mathrm{kg})$ and the mean content of Co in Black tea $(0.2 \mathrm{mg} / \mathrm{kg})$ [36]. The Co content is close to the content in Green tea (0.4$1.2 \mathrm{mg} / \mathrm{kg}$ ), which makes the tea suitable for safe drinking $[25,36]$.

\section{Enrichment Characteristics of Trace Elements in Rock Tea Leaves}

Previous studies have indicated that tea garden soil was the main source of trace elements in tea leaves [8, 37]. The trace elements in the soil can be accumulated in leaves through absorption and migration in the tea trees. Therefore, the enrichment coefficient (enrichment coefficient $=$ the content of the element in the tea leaves / the content of the corresponding element in the soil) can reflect the enrichment ability of the trace elements from the soil into the tea leaves [37].

From Table 5, the difference of the enrichment coefficient values among different elements is apparent, and the difference can vary by an order of magnitude. The average enrichment coefficient values of different elements rank as: $\mathrm{Mn}>\mathrm{Cu}>\mathrm{Hg}>\mathrm{Zn}>\mathrm{Se}>\mathrm{Cd}>\mathrm{Mo}$ $>\mathrm{Co}>\mathrm{As}>\mathrm{Pb}>\mathrm{Cr}$. Apparently, the tea leaf enrichment abilities of $\mathrm{Mn}, \mathrm{Cu}$, and $\mathrm{Hg}$ are the strongest, so that the maximum value of the enrichment coefficients are over 1 .

Table 4. Trace element contents in rock tea leaves.

\begin{tabular}{|c|c|c|c|c|c|c|c|c|c|c|c|}
\hline \multirow{2}{*}{ Item } & \multicolumn{11}{|c|}{ Trace element contents in rock tea leaves / $(\mathrm{mg} / \mathrm{kg})$} \\
\hline & $\mathrm{Hg}$ & As & $\mathrm{Cd}$ & $\mathrm{Pb}$ & $\mathrm{Cr}$ & $\mathrm{Cu}$ & $\mathrm{Zn}$ & $\mathrm{Mn}$ & $\mathrm{Se}$ & Mo & Co \\
\hline Max & 0.151 & 0.065 & 0.057 & 0.369 & 0.775 & 15.060 & 45.023 & 1,401 & 0.239 & 0.323 & 1.264 \\
\hline Min & 0.035 & 0.040 & 0.013 & 0.164 & 0.198 & 7.860 & 27.740 & 133 & 0.088 & 0.017 & 0.039 \\
\hline Mean & 0.065 & 0.054 & 0.030 & 0.262 & 0.294 & 10.873 & 35.682 & 577 & 0.130 & 0.068 & 0.351 \\
\hline SV. & 0.041 & 0.008 & 0.014 & 0.056 & 0.168 & 2.071 & 6.128 & 406 & 0.044 & 0.091 & 0.369 \\
\hline $\mathrm{CV} / \%$ & 63.29 & 15.23 & 48.79 & 21.27 & 57.16 & 19.05 & 17.18 & 70.42 & 34.13 & 134.71 & 105.02 \\
\hline
\end{tabular}


Table 5. Enrichment coefficients of trace elements in rock tea leaves.

\begin{tabular}{|c|c|c|c|c|c|c|c|c|c|c|c|}
\hline Items & $\mathrm{Hg}$ & $\mathrm{As}$ & $\mathrm{Cd}$ & $\mathrm{Pb}$ & $\mathrm{Cr}$ & $\mathrm{Cu}$ & $\mathrm{Zn}$ & $\mathrm{Mn}$ & $\mathrm{Se}$ & $\mathrm{Mo}$ & $\mathrm{Co}$ \\
\hline Max & 1.236 & 0.017 & 0.797 & 0.007 & 0.013 & 1.769 & 0.876 & 2.729 & 0.641 & 0.155 & 0.076 \\
\hline Min & 0.152 & 0.005 & 0.093 & 0.002 & 0.001 & 0.170 & 0.172 & 0.597 & 0.142 & 0.014 & 0.007 \\
\hline Mean & 0.458 & 0.009 & 0.326 & 0.005 & 0.004 & 0.666 & 0.410 & 1.321 & 0.348 & 0.041 & 0.035 \\
\hline $\mathrm{SV}$. & 0.416 & 0.004 & 0.215 & 0.002 & 0.004 & 0.581 & 0.241 & 0.692 & 0.181 & 0.042 & 0.021 \\
\hline $\mathrm{CV} / \%$ & 90.85 & 41.00 & 66.14 & 43.28 & 79.05 & 87.20 & 58.85 & 52.37 & 52.12 & 102.87 & 58.52 \\
\hline
\end{tabular}

The enrichment coefficients of $\mathrm{Zn}$, Se, and $\mathrm{Cd}$ are also in the range of $0.1-1$, indicating that the ability of enrichment is very strong. Significant change in the enrichment coefficients of Co and Mo are measured, from 0.007-0.076 and $0.014-0.155$, respectively. This may indicate that the enrichment of these two elements is easily influenced by the varieties of tea types, tea ages, soil texture, and other factors in the studied area. The enrichment coefficients of non-essential elements such as $\mathrm{As}, \mathrm{Pb}$, and $\mathrm{Cr}$ in the tea leaves are mostly lower than 0.01 , and the ability of enrichment is weakest, which is consistent with [16].

\section{Conclusions}

- The soil in Wuyi rock tea garden area is acidic with high fertility, which is suitable for the growth of tea trees. The content of $\mathrm{Hg}, \mathrm{As}, \mathrm{Cd}, \mathrm{Pb}$, and $\mathrm{Cr}$ in the soil is in accordance with the environmental requirements for areal tea growth (NY/T 853-2004). The studied area belongs to the soil type with adequate $\mathrm{Mn}, \mathrm{Mo}$, and Se, but with a little lack of Co.

- From elemental speciation analysis, oxidizable fraction and residual fraction are the main $\mathrm{Hg}$ fractions in the soil of Wuyi rock tea area. $\mathrm{Cd}$ in the exchangeable fraction is the dominant fraction, which can be easily absorbed by the tea trees. Oxidizable fraction is the main Se fraction and accounts for nearly $72 \%$ of total morphology. $\mathrm{Pb}, \mathrm{Cr}, \mathrm{As}, \mathrm{Cu}, \mathrm{Zn}, \mathrm{Mn}, \mathrm{Mo}$, and $\mathrm{Co}$ are mainly in the residue fraction.

- The assessment results from risk assessment coding method (RAC) and the ratio of secondary phase to primary phase method (RSP) shows that the most serious pollution comes from $\mathrm{Cd}$, whose source is based on anthropogenic sources with high bioavailability. $\mathrm{Hg}$ was largely affected by human activity. Pd was a certain pollutant with high biological effectiveness from RAC values, but not significantly affected by anthropogenic sources from RSP values. The source of Se elements in the soil is diversified, partly from the natural source and mostly from the anthropogenic source. As, $\mathrm{Cr}, \mathrm{Cu}, \mathrm{Zn}, \mathrm{Mn}$, and Co elements in the studied area are mainly from natural sources.

- The contents of $\mathrm{Hg}, \mathrm{As}, \mathrm{Cd}, \mathrm{Pb}, \mathrm{Cr}$, and $\mathrm{Cu}$ of tea samples in the study area are all well below the standard limit of the safety requirements. The tea in most of the tea gardens in the region lacks Mo, so it is recommended to increase the application of Mo fertilizer.

- The rank of average values of the element enrichment coefficients in tea leaves is: $\mathrm{Mn}>\mathrm{Cu}>\mathrm{Hg}>\mathrm{Zn}>\mathrm{Se}$ $>\mathrm{Cd}>\mathrm{Mo}>\mathrm{Co}>\mathrm{As}>\mathrm{Pb}>\mathrm{Cr}$. Among them, Mn, $\mathrm{Cu}$, and $\mathrm{Hg}$ have the strongest enrichment abilities. Non-essential elements such as $\mathrm{As}, \mathrm{Pb}$ and $\mathrm{Cr}$ have the weakest enrichment abilities.

- Overall, the tea leaf samples are all in the safe range, which is beneficial to human health. Nevertheless, in order to guarantee the quality and safety of Wuyi rock tea, we should still strengthen the supervision of the local tea industry, improve tea gardens with reasonable planning, and promote organic tea or high-value-added tea production.

\section{Acknowledgements}

We would like to express our gratitude to Yangbin Liu and Xuehua Chang for laboratory assistance. This research was supported by the Fujian Provincial Spark Project of Science and Technology Department (2016S0059), Fujian Provincial Key Laboratory of Eco-Industrial Green Technology (WYKF2017-12), and the Scientific Research Project of Wuyi University (XD201702).

\section{References}

1. ZONG Y.T., XIAO Q., LU S.G. Chemical fraction, leachability, and bioaccessibility of heavy metals in contaminated soils, Northeast China. Environmental Science and Pollution Research. 23 (23), 24107, 2016.

2. GANGLOFF S., STILLE P., SCHMITT A.D., CHABAUX F. Factors controlling the chemical composition of colloidal and dissolved fractions in soil solutions and the mobility of trace elements in soils. Geochimica et Cosmochimica Acta. 189, 37, 2016.

3. TESSIER A., CAMPBELL P.G.C., BISSON M. Sequential extraction procedure for the speciation of particulate trace metals. Analytical chemistry. 51 (7), 844, 1979.

4. DABEK-ZLOTORZYNSKA E., KELLY M., CHEN H., CHAKRABARTI C.L. Evaluation of capillary electrophoresis combined with a BCR sequential extraction for determining distribution of $\mathrm{Fe}, \mathrm{Zn}, \mathrm{Cu}, \mathrm{Mn}$, and $\mathrm{Cd}$ in airborne particulate matter. Analytica Chimica Acta. 498 (12), 175, 2003 
5. TACK F.M.G., VERLOO M.G. Chemical speciation and fractionation in soil and sediment heavy metal analysis: a review. International Journal of Environmental Analytical Chemistry. 59 (2-4), 225, 1995.

6. GOPE M., MASTO R.E., GEORGE J., HOQUE R.R., BALACHANDRAN S. Bioavailability and health risk of some potentially toxic elements $(\mathrm{Cd}, \mathrm{Cu}, \mathrm{Pb}$ and $\mathrm{Zn})$ in street dust of Asansol, India. Ecotoxicology and Environmental Safety. 138, 231, 2017.

7. DUODU G.O., GOONETILlEKE A., AYOKO G.A. Potential bioavailability assessment, source apportionment and ecological risk of heavy metals in the sediment of Brisbane River estuary, Australia. Marine Pollution Bulletin. 117 (1-2), 523, 2017.

8. KARAK T., ABOLLINO O., BHATTACHARYYA P., DAS K.K., PAUL R.K. Fractionation and speciation of arsenic in three tea gardens soil profiles and distribution of As in different parts of tea plant (Camellia sinensis L.).Chemosphere. 85 (6), 948, 2011.

9. YANG Y., JIN Q., FANG J.M., LIU F.Q., LI A.M., TANDON P., SHAN A.D. Spatial distribution, ecological risk assessment, and potential sources of heavy metal (loid) $\mathrm{s}$ in surface sediments from the Huai River within the Bengbu section, China. Environmental Science and Pollution Research. 24 (12), 11360, 2017.

10. YUAN X.Y., LI T.Y., LI J.Z., YE H.M., GE M.X. Origin and risk assessment of potentially harmful elements in river sediments of urban, suburban, and rural areas. Polish Journal of Environmental Studies. 22 (2), 599, 2013.

11. WANG C., LV S.D., WU Y.S., GAO X.M., LI J.B., ZHANG W.R., MENG Q.X. Oolong tea made from tea plants from different locations in Yunnan and Fujian, China showed similar aroma but different taste characteristics. SpringerPlus. 5 (1), 1, 2016.

12. MILANI R.F., MORGANO M.A., CADORE S. Trace elements in Camellia sinensis marketed in southeastern Brazil: extraction from tea leaves to beverages and dietary exposure. LWT-Food Science and Technology. 68, 491, 2016.

13. RASHID M.H., CHOWDHURY M.A.Z., FATDOUS Z., TANVIR E.M., PRAMANIK M.K., JAHAN I., ALAM M.K., MONIRUZZAMAN M., GAN S.H. Microbial decontamination of gamma irradiated black tea and determination of major minerals in black tea, fresh tea leaves and tea garden soil. LWT-food Science and Technology. 73, $185,2016$.

14. ZHAO H.Y., ZHANG S.L., ZHANG Z.W. Relationship between multi-element composition in tea leaves and in provenance soils for geographical traceability. Food Control. 76, 82, 2017.

15. CHANG C.T., YOU C.F., AGGARWAL S.K., CHUNG C.H., CHAO H.C., LIU H.C. Boron and strontium isotope ratios and major/trace elements concentrations in tea leaves at four major tea growing gardens in Taiwan. Environmental Geochemistry and Health. 38 (3), 737, 2016.

16. KARAK T., BHAGAT R.M. Trace elements in tea leaves, made tea and tea infusion: A review. Food Research International. 43 (9), 2234, 2010.

17. YE H.M., LI G.P., ZHENG M.Z., YUAN X.Y., LIU Y.B., SHI S.Q. Risk evaluation and source tracing on heavy metal contaminations in soil at tea plantations in Wuyishan. Fujian Journal of Agricultural Sciences 31(4), 395, 2016 [In Chinese].

18. 18. YE H.M., YUAN X.Y., HAN L., YIN H., JIN J. Comparison of phosphorus fraction distribution and influencing factors of suspended and surface sediments in the
Tiaoxi watershed, China. Water Science and Technology. 75 (9), 2108, 2017.

19. SAC. (Standardiliztion Adminstration of the People's Republic China). 2004. Environmental condition for tea production area (NY/T 853-2004). Beijing: Chinese Standard Publising House.

20. SAC. (Standardiliztion Adminstration of the People's Republic China). 2012. Hygienic standard for green foodtea (NY/T 288-2012). Beijing: Chinese Standard Publising House.

21. SAC (Standardiliztion Adminstration of the People's Republic China). 2003. Hygienic standard for tea leaves (NY 659-2003). Beijing: Chinese Standard Publising House.

22. LI S.Y., LI H.X., YANG C.L., WANG Y.D., XUE H., NIU Y.F. Rates of soil acidification in tea plantations and possible causes. Agriculture, Ecosystems \& Environment. 233, 60, 2016.

23. MEMON A.R., CHINO M., HIDAKA H., HARA K., YATAZAWA M. Manganese toxicity in field grown tea plants and the microdistribution of manganese in the leaf tissues as revealed by electron probe X-ray micrography. Soil Science and Plant Nutrition. 27 (3), 317, 1981.

24. PEKAL A., BIESAGA M., PYRZYNSKA K. Trace metals and flavonoids in different types of tea. Food Science and Biotechnology. 22 (4), 925, 2013.

25. LI L.H., FU Q.L., ACHAL V., LIU Y.L. A comparison of the potential health risk of aluminum and heavy metals in tea leaves and tea infusion of commercially available green tea in Jiangxi, China. Environmental Monitoring and Assessment. 187 (5), 228, 2015.

26. KHAN Z.I., AHMAD K., YASMEEN S., AKRAM N.A., ASHRAF M., MEHMOOD N. Potential health risk assessment of potato (Solanum tuberosum L.) grown on metal contaminated soils in the central zone of Punjab, Pakistan. Chemosphere. 166, 157, 2017.

27. YE X., GUO Y.L., WANG G., GE H.L. Investigation and analysis of soil molybdenum in the Tieguanyin tea plantations of Fujian Province. Plant Nutrition and Fertilizer Science. 17 (6), 1372, 2011 [In Chinese].

28. HU Q.H., PAN G.X., ZHU J.C. Effect of fertilization on selenium content of tea and the nutritional function of Seenriched tea in rats. Plant and Soil. 238 (1), 91, 2002.

29. SHAHBAZ M., KUZYAKOV Y., SANAULLAH M., HEITKAMP F., ZELENEV V., KUMAR A., BLAGODATSKAYA E. Microbial decomposition of soil organic matter is mediated by quality and quantity of crop residues: mechanisms and thresholds. Biology and Fertility of Soils. 53 (3), 287, 2017.

30. ZHANG H.Z., GUO Q.J., YANG J.X., MA J., CHEN G., CHEN T.B., ZHU G.X., WANG J., ZHANG G.X., WANG X., SHAO C.Y. Comparison of chelates for enhancing Ricinus communis L. phytoremediation of $\mathrm{Cd}$ and $\mathrm{Pb}$ contaminated soil. Ecotoxicology and Environmental Safety. 133, 57, 2016.

31. SINGH K.P., MOHAN D., SINGH V.K., MALIK A. Studies on distribution and fractionation of heavy metals in Gomti river sediments - a tributary of the Ganges, India. Journal of Hydrology. 312 (1-4), 14, 2005.

32. WANG F.Y., CHEN J.S., FORSLING W. Modeling sorption of trace metals on natural sediments by surface complexation model. Environmental Science \& Technology. 31 (2), 448, 1997.

33. CHEN J.S., DONG L., DENG B.S., WANG L.B., WANG M., XIONG Z.L. Modeling study on copper partitioning in sediments: A case study of Poyang Lake. Acta Scientiae Circumstantiae. 7(2), 140, 1987 [In Chinese]. 
34. VIARD B., PIHAN F., PROMEYRAT S., PIHAN J.C. Integrated assessment of heavy metal $(\mathrm{Pb}, \mathrm{Zn}, \mathrm{Cd})$ highway pollution: bioaccumulation in soil, Graminaceae and land snails. Chemosphere. 55 (10), 1349, 2004.

35. LI X., ZHANG Z.W., LI P.W., ZHANG Q., ZHANG W., DING X.X. Determination for major chemical contaminants in tea (Camellia sinensis) matrices: A review. Food Research International. 53 (2), 649, 2013.
36. SHEN F.M., CHEN H.W. Element composition of tea leaves and tea infusions and its impact on health. Bulletin of Environmental Contamination and Toxicology. 80 (3), 300, 2008.

37. ZHAO H.Y., ZHANG S.L., ZHANG Z.W. Relationship between multi-element composition in tea leaves and in provenance soils for geographical traceability. Food Control. 76, 82, 2017. 